\title{
Specific phytoplankton signatures and their relationship to hydrographic conditions in the coastal northwestern Mediterranean Sea
}

\author{
José Bustillos-Guzmán, Hervé Claustre, Jean-Claude Marty \\ Observatoire Océanologique de Villefranche, CNRS-INSU, Laboratoire de Phł̧sique et Chimie Marines, B.P. 08, \\ F-06230 Villefranche-sur-mer, France
}

\begin{abstract}
Between March 1992 and April 1993, an intensive sampling pregram was carried out at a coastal station in the Northwestern Mediterranean Sea to study the relations hy between phytoplankton distributions, as evaluated by taxonomic pigments, and the hydrographyc structures of the water column. The study period covered the range of hydrographic conditions whict prevail in the Mediterranean Sea. The 0 to $75 \mathrm{~m}$ integrated chlorophyll a concentration averaged $23.3 \mathrm{mg} \mathrm{m}^{2}$, with the highest values (above $45 \mathrm{mg} \mathrm{m}^{-2}$ ) restricted to semi-mixed periods. The major phricplankton signature and water column structure relationshups were: (1) phytoplanktonıc prokaryotes (xyanobacteria and prochlorophytes! appear sensitive to water column mixing with prochlorophytes ineing the most sensitive group as strong stratification is associated with the highest biomass found mainly in deeper waters; (2) prymnesiophytes and chrysophytes (19'-BF and 19'-HF) appear the most toundant under a varjety of conditions and therefore seem able to adapt to various water column struc tures; (3) diatoms bloom in semi-mixed conditions, but while these conditions are necessary, they are rat sufficient for bloom formation; and (4) green chlorophyll b-containing flagellates appear to require stong mixing. During the stratification period, 2 noticeable wind-induced mixing events occurred, and while the first did not have any marked influence on the phytoplankton community, the second was followed by a subsurface development of green flagellates and diatoms. This second wind-mixing event also altered the vertical prokaryote distribution, but 1 wk after this perfurbation vertical segregation of prochlorophytes and cyanobacteria was reestablished. The results suggest that, while different phituplankton taxa are generally adapted to specific water column structures, this is not always the case especially at small scales where specific light/nutrient requirements may have to be met.
\end{abstract}

KEY WORDS: Cyanobacteria Chemotaxonomy Hydrography HPLC Afeciterranean Sea - Oligotrophic sea Pigments. Phytoplankton. Prochlorophytes

\section{INTRODUCTION}

For most of the world's oceans, it is recognized that phytoplankton signatures may characterize specific hydrographic conditions. For example, large species (mostly diatoms) dominate in upwelling environments while minute picophytoplankton are a common feature of the oligotrophic stratified open ocean (e.g. Chisholm 1992). Nevertheless, superimposed on a phytoplankton signature at the macroscale (regional as well as seasonal), a particular phytoplankton dynamic exists at the mesoscale (Harris 1984) which generally corresponds to changes in hydrodynamic conditions, a result, for example, of transition between different oceanic provinces atmospheric forcing events. These structures fawar high carbon fixation rates by particular phytoplankton species, often diatoms, so that, although limited in time and space, these transitional structures are of considerable importance for fisheries and carbon budgets at higher scales (Claustre 1994, Townsend et a 1994). Therefore, research has increasingly been focused on phytoplankton dynamics and associated bioge ochemical properties at the mesoscale. For spatial sturies, this may concern the phytoplankton signature associated with the transition between the coastal arld the open ocean zone (Welschmeyer, 1994) as well as with the effect of cross-frontal secondary circulation on phytoplankton community 
structure and primary production (Claustre et al. 1994). Numerous temporal studies have focused on the relationship between seasonal forcing and phvtoplankton blooms (e.g North Atlantic bloom experiment; Harrison et al. 1993, Verity et al. 1993, Weeks et al. 1993) as well as on the effect of atmospheric perturbation on resulting biogeochemical properties (DiTullio \& Laws 1991).

The prevailing uncertainty about the relationship between phytoplankton dynamics and hydrodynamism at small and mesoscales, mainly results from difficulties in conducting studies with high resolution. Such constraints can be overcome for spatial studies (as soon as structures have been located from synoptic observation, e.g. ship or satellite), but major difficulfies remain for temporal studies, especially those dedicated to the open oligotrophic ocean where temporal variability is the most difficult to assess, because it is difficult to predict. Temporal variability can be solely assessed by opportunity (DiTullio \& Laws 1991), or by intensive sampling where a location is occupied for a sufficient time to be sure that seasonal forcing will be integrated (Harrison et al. 1993, Verity et al. 1993, Kreeks et al. 1993). High sampling frequencies also imply high frequency of analysis. When dedicated to phytoplankton dynamics, classical phytoplankton evaluation (e.g. microscopy) fails to resolve the smallest organisms (e.g. Prochlorococcus spp.). Moreover, these methods are time-consuming, limiting their use for providing a fine temporal and spatial description of phytoplankton community dynamics. The pigment chemataxonomic approach, specifically carotenoids (Liaaen-Jensen 1979, 1990), appears to be a good alternative, able to overcome most of these methodological constraints: carotenoids are quantitative, cover the whole size range of phytoplankton and can be applied for a large sample set (e.g. Gieskes \& Kraay 1983, 198 Gi Gieskes et al. 1988, Everitt et al. 1990).

Most of the Mediterranean Sea is oligotrophic (Minas \& Bonin 1988), and its hydrological regime has been extensively studied (e.g. Bethoux \& Prieur i983). The water column is well stratified in summer, well mixed in winter, and transition periods of stratificetion occur during spring (March-April) and late fall-early winter (November-December). These changes in the hydrological regime are highly related to phytoplankton community dynamics (e.g. Rassoulzadegan 1979, Morel \& André 1991). Coastal areas of the Worthwestern Mediterranean Sea are also characterzed by the presence of this well-defined hydrographic cycle (e.g. Nival \& Corre 1976. Etienne et al. 1991) and, as such, are pertinent case studies where high sampling frequencies can be developed to examine the relationship between phytoplankton dynamics and hydrological forcing, especially at small and mesoscales.
The present study investigated phytoplankton dynamics, as evaluated by pigment biomarkers, and hydrodynamics with a high temporal (weekly or biweekly) and spatial (9 depths in a 0 to $75 \mathrm{~m}$ layer) resolution during a 14 mo period at a coastal station of the Ligurian Sea (Northwestern Mediterranean Sea). The precise aim was to identify what phytoplankton signatures could be associated with specific, welldefined hydrographic conditions and determine if particular taxa could be associated with transitional periods between stratified and mixed conditions.

\section{MATERIALS AND METHODS}

Hydrographic observations as well as pigments and nitrate measurements were conducted between March 1992 and April 1993 at a fixed coastal station of the Northwestern Mediterranean Sea (Stn B: $43^{\circ} 41^{\prime} 10^{\prime \prime} \mathrm{N}$ and $7^{\circ} 19^{\prime} 00^{\prime \prime} \mathrm{E}_{i}$ for site background, see Etienne et al. 1991). Vertical profiles of temperature and density were obtained weekly or biweekly using a Seabird conductivity, temperature and density profiler (CTD) system. Water samples for nitrate and pigment analysis were collected using a Van Dorn bottle system at 0,5 , $10,20,30,40,50,60$, and $75 \mathrm{~m}$ depth. Nitrate samples were analyzed using a EV2 Alliance Instrument according to Tréguer \& Le Corre (1975). For pigment determinations, $2 \mathrm{l}$ of seawater were filtered onto $25 \mathrm{~mm}$ GF/F Whatman glass fiber filters which were immediately stored at $-20^{\circ} \mathrm{C}$. Extraction was carried out under dim light conditions. Filters were ground and sonicated in $2 \mathrm{ml}$ of high performance liquid chromatograph (HPLC) grade methanol and then clarified by filtration ( $25 \mathrm{~mm} \mathrm{GF/C} \mathrm{Whatman} \mathrm{glass} \mathrm{fiber} \mathrm{filters).}$ An aliquot $(500 \mu l)$ of the clarified extract was mixed with $250 \mu$ of $1 \mathrm{M}$ ammonium acetate solution and used to fill a $200 \mu$ l loop of the HPLC system [CM 4000 Milton Roy Constametric Pump, $10 \times 0.46 \mathrm{~cm} 3 \mu \mathrm{m}$ ODS Hypersil column (Société Française de Chromato colonne), and a Milton Roy SM spectromonitor set up at $440 \mathrm{~nm}$. Solvent A (MeOH:1 $N$ aq. amonium acetate, 80:20) and Solvent $\mathrm{B}(\mathrm{MeOH}$ :acetone, 60:40) were programmed at $1 \mathrm{ml} \mathrm{min}{ }^{-1}$ on the following gradient (Solvent $A$, Solvent B): $(0 \mathrm{~min} ; 100,0),(10 \mathrm{~min}$; $0,100),(15 \mathrm{~min} ; 0,100),(18 \mathrm{~min} ; 100,0)$. Chlorophylls and carotenoids were detected by their absorbance at $440 \mathrm{~nm}$. Procedures for pigment identification and quantification have been described elsewhere (Claustre et al. 1994, Claustre \& Marty 1995). The RP 1.8 HPLC system used here provides a sufficient, although not baseline, resolution of chlorophyll $a$ (chl a) and divinyl-chlorophyll a (Dv-chl a) to achieve quantification. Lowest detection limits of Dv-chl a ranged between 5 and $10 \mathrm{ng} l^{-1}$. 
The chemotaxonomic significance of diagnostic pigments is given in Table 1 . However, the estimation of the contribution of green flagellates using chlorophyll $b$ (chl b) and of cyanobacteria via zeaxanthin required some deconvolution because: (1) chl $b$ and Dv-chl $b$ coelute, (2) lutein (green flagellates) and zeaxanthin coelute, and (3) both prochlorophytes and cyanobacteria contribute to zeaxanthin. This was achieved using the following procedure, depending on the absence or presence of prochlorophytes. (1) In the absence of prochlorophytes (no Dv-chl a), the slope of the regression between the $c h l b$ and zeaxanthin-lutein was assumed to represent the chl $b$ lutein ${ }^{-1}$ ratio in green flagellates. This ratio was determined for each hydrographic condition (see 'Results: Hydrographic conditions'). The estimated lutein (product of the ratio by chlorophyll $b$ concentration) was subsequently subtracted from the zeaxanthinlutein stock to obtain the zeaxanthin strictly associated with cyanobacteria. (2) In the presence of prochlorophytes, a multiple regression analysis of the concentrations of Dv-chl a vs [zeaxanthin + lutein] and [Dv-chl $b+$ chl $b$ ] was performed and the resulting constants were assumed to represent $\mathrm{Dv}-\mathrm{Chl}$ a zeaxanthin ${ }^{-1}$ and Dv-chl a Dv-chl $b^{-1}$ ratios in prochlorophytes (e.g. Gieskes et al. 1988, Barlow et al. 1993). These ratios were determined at each sampling depth in order to take into consideration the light dependency of such criteria in prochlorophytes (Goericke \& Repeta 1993, Partensky et al. 1993). This procedure was facilitated by the fact that, during the presence of prochlorophytes (Dv-chl a), green flagellates (chl b) were absent (except in 1 case, see Fig. 6). This was confirmed by the purity of zeaxanthin and Dv-chl $b$ peaks using photodiode array detection. Then, for cyanobacteria, zeaxanthin was simply estimated by subtracting prochlorophyte zeaxanthin from the whole zeaxanthin signal.

Table 1. Taxonomic pigment significance. 19'-BF+19'-HF: $19^{\prime}-$ butanoyloxyfucoxanthin + 19'-hexanoyloxyfucoxanthin; Dv-chl a: divinyl chlorophyll $a_{i}$ Dv-chl $b$ : divinyl chlorophyll $b$. 1 : Wright \& Jeffrey 1987; 2: Bjornland et al. 1988; 3: Hooks et al. 1988; 4: Liaaen-Jensen 1985; 5: Jeffrey 1974; 6: Arpin et al. 1976; 7: Gieskes \& Kraay 1986; 8: Jeffrey 1976; 9: Gieskes \& Kraay 1983; 10: Guillard et al. 1985; 11. Kana \& Glibert 1987; 12: Chisholm et al. 1992; 13: Goericke \& Repeta 1992

\begin{tabular}{|lll|}
\hline Pigment signature & Phytoplankton group & Sources \\
\hline Fucoxanthin & Diatoms & $1,2,3,4$ \\
Peridinin & Dinoflagellates & 5 \\
19'-BF+19'-HF & Nanoflagellates & $1,2,3,4,6,7$ \\
Chlorophyll $b$ & Green flagellates & 8 \\
Alloxanthin & Cryptophytes & 9 \\
Zeaxanthin & Cyanobacteria & 10,11 \\
DV-chl $a$, DV-chl b & Prochlorophytes & 12,13 \\
aChlorophyll c-containing nanoflagellates, mostly prym- \\
nesiophytes and chrysophytes \\
\hline
\end{tabular}

\section{RESULTS}

\section{Hydrographic conditions}

Water temperature was homogeneous with depth $\left(13^{\circ} \mathrm{C}\right.$ ) at the beginning (March 1992) and at the end (December 1992 to March 1993) of the study (Fig. 1 upper panel). Between both periods, waters were stratified and surface temperature reached $26^{\circ} \mathrm{C}$ in July-August. During stratification, 2 wind-driven events (data not shown; 9 June and 3 September) induced a mixing of the top $40 \mathrm{~m}$ layer. In the study area, density is mostly temperature-driven so that isopycnal contours (data not shown) match temperature. To characterize the degree of water column stability, a stratification index was computed (Peterson \& Bellantoni 1987) as the difference of density $\mathrm{m}^{-1}$ ( 0 to $75 \mathrm{~m}$ ) calculated from each $5 \mathrm{~m}$ data. The value of

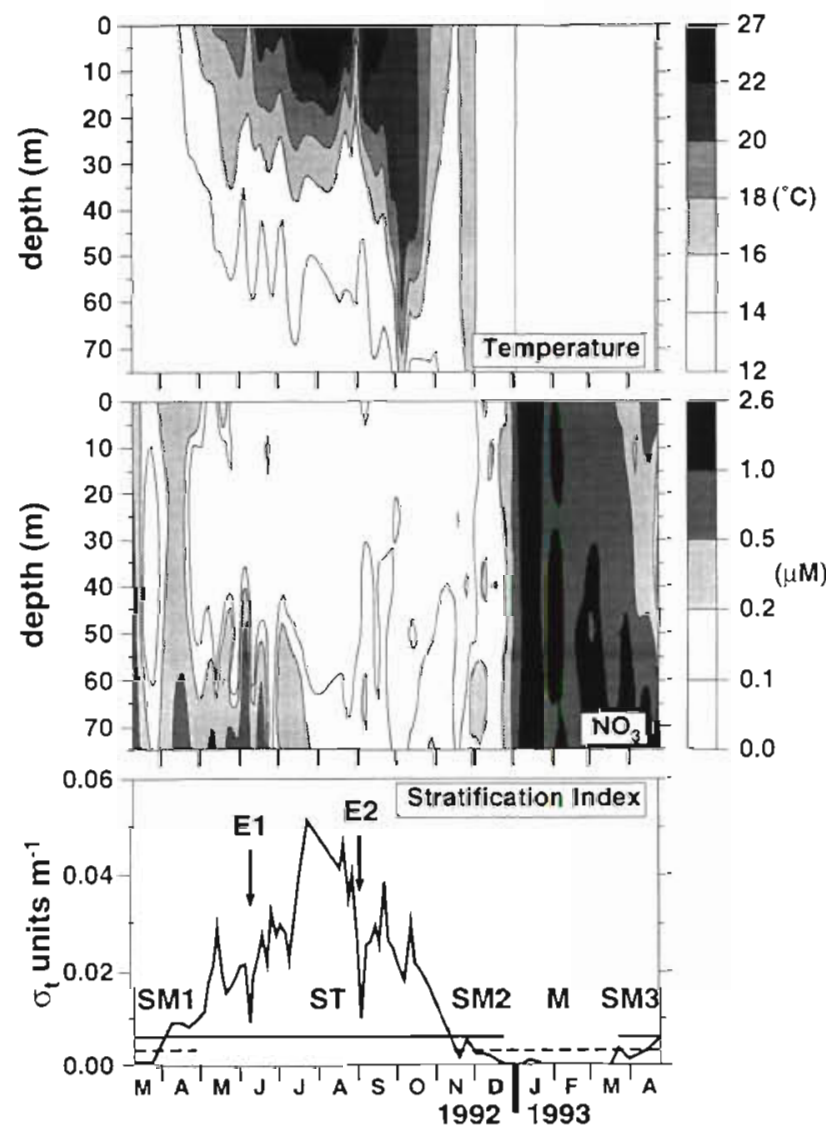

Fig. 1. Variations in hydrographic and nitrate $\left(\mathrm{NO}_{3}\right)$ conditions at Stn B. Northwestern Mediterranean Sea, between March 1992 and April 1993. Stratification index in the lower panel calculated as the average density difference $\mathrm{m}^{-1}$ of the 0 to $75 \mathrm{~m}$ layer $\left(\sigma_{1}\right.$ units $\left.\mathrm{m}^{-1}\right)$. ST: summer stratified period; M: mixed period; SM1 and SM3: semi-mixed period, spring conditions: SM2: semi-mixed period, fall-winter conditions; E1 and E2: atmosphere events associated with wind forcing during the ST penod 

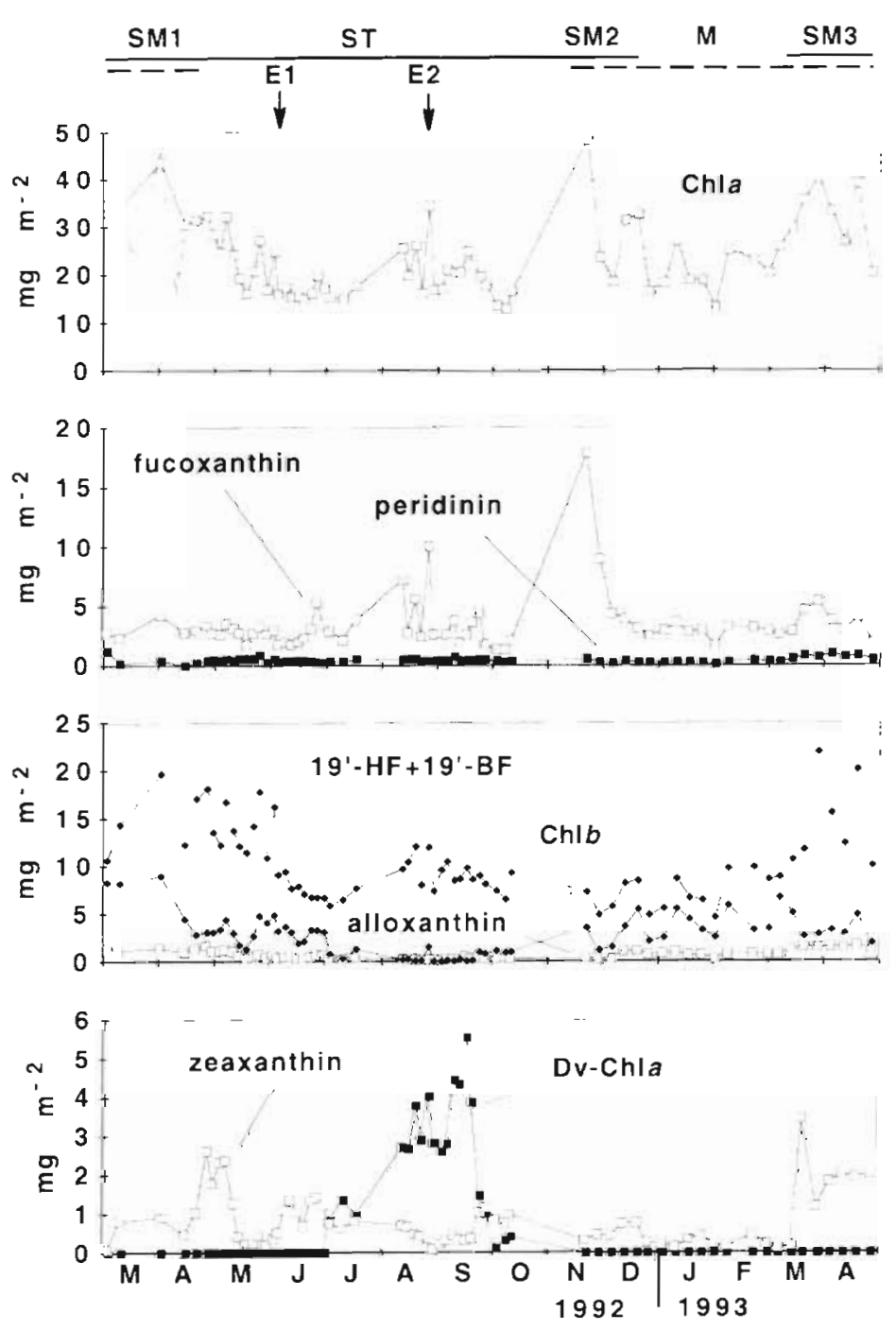

Fig. 2. Variations in 0 to $75 \mathrm{~m}$ integrated pigment concentration at Stn B between March 1992 and April 1993. Uppermost part of figure refers to stratification conditions as defined in Fig. 1 (stratification index). In the top panel the dashed line (March to April 1992) represents the chlorophyll a variation as measured by spectrophotometry (Charra R. unpubl. datal to fill unsampled period. 19'-HF+19'-BF: 19'-hexanoyloxyfucoxanthin $+19^{\prime}$ butanoyloxyfucoxanthin; Dv-Chl a: divinyl chlorophyll a

this index permits definition of specific periods associated with defined hydrological characteristics, namely (Fig. 1 bottom panel): a summer stratified period (hereafter ST), a mixed period (hereafter $M$ ) and 3 semimixed periods (SM1 and SM3 for spring conditions and SM2 for fall-winter conditions). Superimposed on these conditions, the atmospheric events associated with wind forcing during the ST period are referred to as E1 and E2.

Under stratified conditions, nitrates were always below $0.1 \mu \mathrm{M}$ in the upper $50 \mathrm{~m}$, except during the 2 incursions associated with the E1 and E2 mixing events
(Fig. 1 middle panel). Below the $14^{\circ} \mathrm{C}$ isotherm, nitrate levels higher than $0.1 \mu \mathrm{M}$ were always recorded. In contrast, for the mixed winter conditions, nitrate concentrations were constant with depth and above (1 $\mu M$ ) while for semi-mixed conditions nitrate concentrations were still homogeneous but always below $0.5 \mu \mathrm{M}$.

\section{Integrated pigments variation}

The temporal variations of the 0 to $75 \mathrm{~m}$ integrated concentrations of taxonomic pigments are shown in Fig. 2, and Table 2 summarizes the average values for the previously defined periods. The integrated chlorophyll a concentration varies between 13 and $48 \mathrm{mg}$ $\mathrm{m}^{-2}$. On average, higher chlorophyll a levels ( $t$-test, $\quad \mathrm{p}<0.01$ ) were recorded for semimixed conditions (34 and $32 \mathrm{mg} \mathrm{m}^{-2}$ for SM1 and SM3, respectively) than for stratified (20 $\mathrm{mg} \mathrm{m}^{-2}$ ) or mixed (22 $\mathrm{mg} \mathrm{m}^{-2}$ ) conditions (Table 2). For the 2 semi-mixed conditions, high pigment concentrations levels were not associated with the same phytoplankton populations. When stratification began (SM1 and SM3) increases of chlorophyll a were associated with increases in phytoplankton containing $19^{\prime}-\mathrm{BF}$ and $19^{\prime}-\mathrm{HF}$, while for SM2, i.e. with the erosion of the thermocline, the chlorophyll a increase was mainly due to a diatom bloom with a particularly high value of fucoxanthin (18 $\mathrm{mg} \mathrm{m}^{-2}$ ), on 25 November. Rapid change in fucoxanthin concentrations were also recorded during stratified conditions but associated with the E2 event (from 2 to $10 \mathrm{mg} \mathrm{m}^{-2}$ ). Prochlorophytes were exclusively associated with such stratified conditions with divinyl chlorophyll a reaching values up to $6 \mathrm{mg} \mathrm{m}^{-2}$ (average value of $1.2 \mathrm{mg}$ $\mathrm{m}^{-2}$, Table 2); this pigment was below the detection limit for other periods (Fig. 2 and Table 2). The highest cyanobacteria zeaxanthin concentration was recorded for the SM3 (up to $3 \mathrm{mg} \mathrm{m}^{-2}$ ) and at the end of SM1/beginning of ST, while the lowest cyanobacteria values are associated with mixed conditions. Highest values in chlorophyll $b$ were recorded during SM1 and the lowest during ST Alloxanthin integrated concentrations were very low throughout but the highest average values were recorded for SM1 and SM2 conditions. Peridinin concentration was always below $1.2 \mathrm{mg} \mathrm{m}^{-2}$.

The relative contribution of the different groups to the total chlorophyll a (chlorophyll a + divinyl chloro- 
Table 2. Mean integrated pigment concentration $\left(\mathrm{mg} \mathrm{m}^{-2}\right)$ for the whole period studied and for each hydrographic condition. Standard deviation in parentheses. n: sample number. 19'-BF+19'-HF: 19'-butanoyloxyfucoxanthin +19'-hexanoyloxyfucoxanthin; Dv-Chl a: divinyl chlorophyll a

\begin{tabular}{|c|c|c|c|c|c|c|c|}
\hline \multirow[t]{3}{*}{ Pigments } & \multirow{2}{*}{\multicolumn{2}{|c|}{$\begin{array}{l}\text { Whole period } \\
n=66\end{array}$}} & \multicolumn{5}{|c|}{ Hydrographic conditions (defined in Fig. 1) } \\
\hline & & & Stratified & Mixed & SM1 & SM2 & SM3 \\
\hline & Mean & Range & $n=38$ & $\mathrm{n}=10$ & $n=6$ & $n=6$ & $n=6$ \\
\hline Chlorophyll a & $23.3(8.0)$ & $13.0-48.0$ & $20.0(5.0)$ & $22.0 \quad(5.0)$ & $34.0 \quad(4.9)$ & $28.0(11.0)$ & $32.0(7.6)$ \\
\hline Fucoxanthin & $3.5(2.3)$ & $1.0-10.0$ & $3.0(1.6)$ & $3.0(0.5)$ & $3.0(0.6)$ & $7.0(5.8)$ & $4.0(1.2)$ \\
\hline Peridinin & $0.4(0.2)$ & $0.0-1.0$ & $0.4(0.1)$ & $0.3(0.1)$ & $0.4(0.4)$ & $0.3[0.3\}$ & $0.7(0.1)$ \\
\hline $19^{\prime}-\mathrm{BF}+19^{\prime}-\mathrm{HF}$ & $10.0(3.9)$ & $4.0-22.0$ & $10.0(3.0)$ & $8.0(2.0)$ & $14.0(3.5)$ & $6.0(6.0)$ & $15.0(4.8)$ \\
\hline Chlorophyll $b$ & $3.0(2.1)$ & $0.5-9.0$ & $2.0(1.5)$ & $4.0(1.4)$ & $6.0(2.8)$ & $3.0(3.0)$ & $3.0(0.9)$ \\
\hline Alloxanthin & $0.7(0.4)$ & $0.2-2.0$ & $0.5(0.2)$ & $0.8(0.2)$ & $1.0(0.2)$ & $0.6(0.6)$ & $1.4(0.1)$ \\
\hline Zeaxanthin & $0.8(0.7)$ & $1.0-10.0$ & $0.8(0.5)$ & $0.2(0.1)$ & $0.6(0.8)$ & $0.5(0.5)$ & $2.0(0.7)$ \\
\hline Dv-Chl a & $0.7(1.4)$ & $0.0-5.5$ & $1.2(1.6)$ & $0.0(0.0)$ & $0.0(0.0)$ & $0.0(0.0)$ & $0.0(0.0)$ \\
\hline
\end{tabular}

phyll a) was evaluated using a multiple correlation analysis, according to Barlow et al. (1993), between the diagnostic integrated pigment concentration and chlorophyll a (the divinyl chlorophyll a was only added to the final equation):

[Chlorophyl $a+$ divinyl chlorophyll a] $=2.86$

+1.05 [19'-BF+19'-HF] +1.24 [chlorophyll b]

+1.84 [fucoxanthin] +3.34 [alloxanthin]

+2.25 [peridinin] +0.83 [zeaxanthin]

+ [divinyl chlorophyll $a$ ]; $\left(\mathrm{r}^{2}=0.82 ; \mathrm{p}<0.01\right)$.

In this equation, the constant values, which represent the ratio of diagnostic pigment to chlorophyll $a$, have been constrained for dinoflagellates (Everitt et al. 1990), cryptophytes (Claustre et al. 1994) and cyanobacteria (Kana et al. 1988), since in a preliminary similar analysis (results not shown) the constant values were unrealistic. These ratios are in the range given by Barlow et al. (1993) for a similar analysis in the north Atlantic Ocean and by Everitt et al. (1990) using an

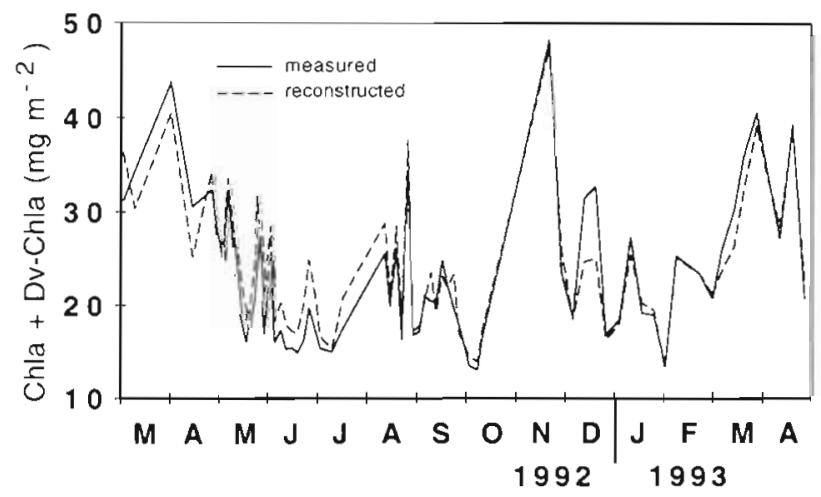

Fig. 3. Comparison between temporal variation of measured (continuous line) and reconstructed (dashed line, Eq. 1 in 'Results - Hydrographic conditions') total autotrophic biomass (chlorophyll a + divinyl chlorophyll a) at Stn B between March 1992 and April 1993 iterative procedure for the western equatorial Pacific. Using such a procedure, the agreement between measured and reconstructed chlorophyll $a+$ divinyl chlorophyll $a$ is good (Fig. 3), which allows a more accurate estimate of the contribution of various taxa to total chlorophyll a (Fig. 4 and Table 3). Nano-sized flagellates (green flagellates, prymnesiophytes, chrysophytes and cryptophytes) were ubiquitous throughout the study and contributed between 46 and $80 \%$ of the total chlorophyll a. Nanoflagellates which contain 19'-BF and 19'-HF were the dominant contributor in this nano-size fraction. Diatoms represented on average more than $40 \%$ of the total chlorophyll a land up to $70 \%$ ) in the semi-mixed conditions (SM2), but their contribution during the ST period was also highly variable and represented up to $40 \%$ of the chlorophyll a in some cases. Prochlorophytes were the third most important group when stratification was maximal, and their contribution as high as $20 \%$ of the overall chlorophyll a.

\section{Vertical distribution}

Vertical distribution data for chlorophyll a and other taxonomic pigments (except alloxanthin and peridinin, since they did not contribute significantly to the autotrophic biomass) allowed us to refine the general trends described above (Fig. 5). Lowest chlorophyll a concentrations (below $200 \mathrm{ng} \mathrm{l}^{-1}$ ) were recorded below $60 \mathrm{~m}$ all year around and during the $M$ period over the whole water column. For SM1 and SM3 conditions, the chlorophyll maxima were generally associated with the top $20 \mathrm{~m}$ while for SM2 conditions, where highest integrated concentration were recorded $148 \mathrm{mg} \mathrm{m}^{-2}$, Fig. 3), the maxima ( $\left.800 \mathrm{ng} \mathrm{l}^{-1}\right)$ was deeper $(40 \mathrm{~m})$. The other peak chlorophyll a concentration (up to $600 \mathrm{ng}$ $\mathrm{l}^{-1}$ at $10 \mathrm{~m}$ ) was associated with the second E2 mixing event. 
Table 3. Phytoplanktonic group contribution (\%) to total autotrophic biomass (chlorophyll a + divinyl chlorophyll a) as determined by the taxonomic pigmeat concentration and Eq. (1) 'Results-Hydrographic conditions' Standard deviation in parenthesis n: sample number

\begin{tabular}{|c|c|c|c|c|c|c|c|}
\hline \multirow[t]{3}{*}{ Group } & \multirow{2}{*}{\multicolumn{2}{|c|}{$\begin{array}{l}\text { Whole period } \\
\qquad n=66\end{array}$}} & \multicolumn{5}{|c|}{ Hydrographic conditions (defined in Fig. 1) } \\
\hline & & & \multirow{2}{*}{$\begin{array}{c}\text { Stratified } \\
\mathrm{n}=38\end{array}$} & \multirow{2}{*}{$\begin{array}{l}\text { Mixed } \\
n=10\end{array}$} & \multirow{2}{*}{$\begin{array}{l}\text { SM1 } \\
n=6\end{array}$} & \multirow{2}{*}{$\begin{array}{l}\mathrm{SM} 2 \\
\mathrm{n}=6\end{array}$} & \multirow{2}{*}{$\begin{array}{l}S M 3 \\
n=6\end{array}$} \\
\hline & Mean & Range & & & & & \\
\hline Diatoms & $26.0(11.0)$ & $12.0-70.0$ & $26.0(8.9)$ & $24.0(3.7)$ & $16.0(1.9)$ & $42.0(21.0)$ & $21.0(2.5)$ \\
\hline Dinoflagellates & $4.0(1.6)$ & $0.0-8.0$ & $4.0(1.2)$ & $2.0(0.7)$ & $2.0(4.1)$ & $2.0(0.3)$ & $5.0(0.8)$ \\
\hline Nanoflagellates & $45.0(12.1)$ & $15.0-75.0$ & $50.0(11.4)$ & $45.0(3.9)$ & $45.0(6.9)$ & $26.0\{5.5\}$ & $48.0(7.1)$ \\
\hline Green flagellates & $140(9.3)$ & $0.0-33.0$ & $11.0(9.3)$ & $23.0(4.8)$ & $23.0(7.8)$ & $12.0(4.7)$ & $11.0(2.3)$ \\
\hline Cryptophytes & $9.0(4.3)$ & $2.0-21.0$ & $8.0(3.5)$ & $12.0(1.7)$ & $12.0(1.6)$ & $8.0(4.6)$ & $15.0(3.0)$ \\
\hline Cyanobacteria & $3.0 \quad(2.2)$ & $0.0-8.0$ & $3.0(2.1)$ & $1.0(0.5)$ & $1.0(0.8)$ & $1.0(0.5)$ & $5.0(2.0)$ \\
\hline Prochlorophytes & $3.0(5.5)$ & $0.0-18.0$ & $6.0(6.3)$ & $0.0(0.0)$ & $0.0(0.0)$ & $0.0(0.0)$ & $0.0 \quad(0.0)$ \\
\hline
\end{tabular}

Fucoxanthin maximum abundance was recorded between 20 and $50 \mathrm{~m}$ depth, except for mixed conditions and for the bloom during SM2 where diatoms occupied the whole water column. Maximum values of $19^{\prime}-\mathrm{BF}$ and $19^{\prime}$-HF were observed in the top 40 to $50 \mathrm{~m}$ layer (up to $400-500 \mathrm{ng} \mathrm{\textrm {l } ^ { - 1 }}$ ) during SM1 and SM2 and below $40 \mathrm{~m}$ during ST (up to $200 \mathrm{ng} \mathrm{l}^{-1}$ ) and follow- ing E2. Green flagellates were more abundant (up to $230 \mathrm{ng} \mathrm{l}^{-1}$ ) during the SM1 and $\mathrm{M}$ periods and also during the wind-driven perturbations (Fig. 6). Depth distribution of the prokaryote pigment zeaxanthin (cyanobacteria) and divinyl chlorophyll a (prochlorophytes; Fig. 6) clearly shows that they have complementary distributions in the water column: cyanobacteria are restricted to the upper layers (generally above $40 \mathrm{~m}$ ) with maximal values in the top $10 \mathrm{~m}$, while prochlorophytes dominate at depth with the highest divinyl chlorophyll $a$ concentration below $30 \mathrm{~m}$. Moreover, it is clear from Fig. 5 that mixed conditions were not associated with the development of these prokaryotic phytoplankton

\section{DISCUSSION}

The study site, although coastal, is a good model of the succession of hydrological conditions that may prevail in the Northwestern part of the Mediterranean Sea (Gostan 1967). The deep winter mixing brings up new nutrients into the upper layers. This surface layer becomes stabilized during spring and summer and is characterized by a well-established pycnocline which constitutes a strong barrier to nutrient replenishment of surface layers. We were able to follow and to associate phytoplankton dynamics to overall seasonal changes in environmental conditions. Nevertheless, for such oligotrophic conditions, and particularly during summer stratification, wind-driven events may disrupt this stabilization and allow injection of significant new nutrients in the surface layers, which modifies phytoplankton community dynamics and presumably has implications for the food chain structure. The sampling strategy we used,
Fig. 4. Contribution (as \%) of the different phytoplankton groups to the total autotrophic biomass (chlorophyll a + divinyl chlorophyll a) at Stn B between March 1992 and April 1993. Uppermost part of figure refers to stratification conditions as defined in Fig. 1 (stratification index 


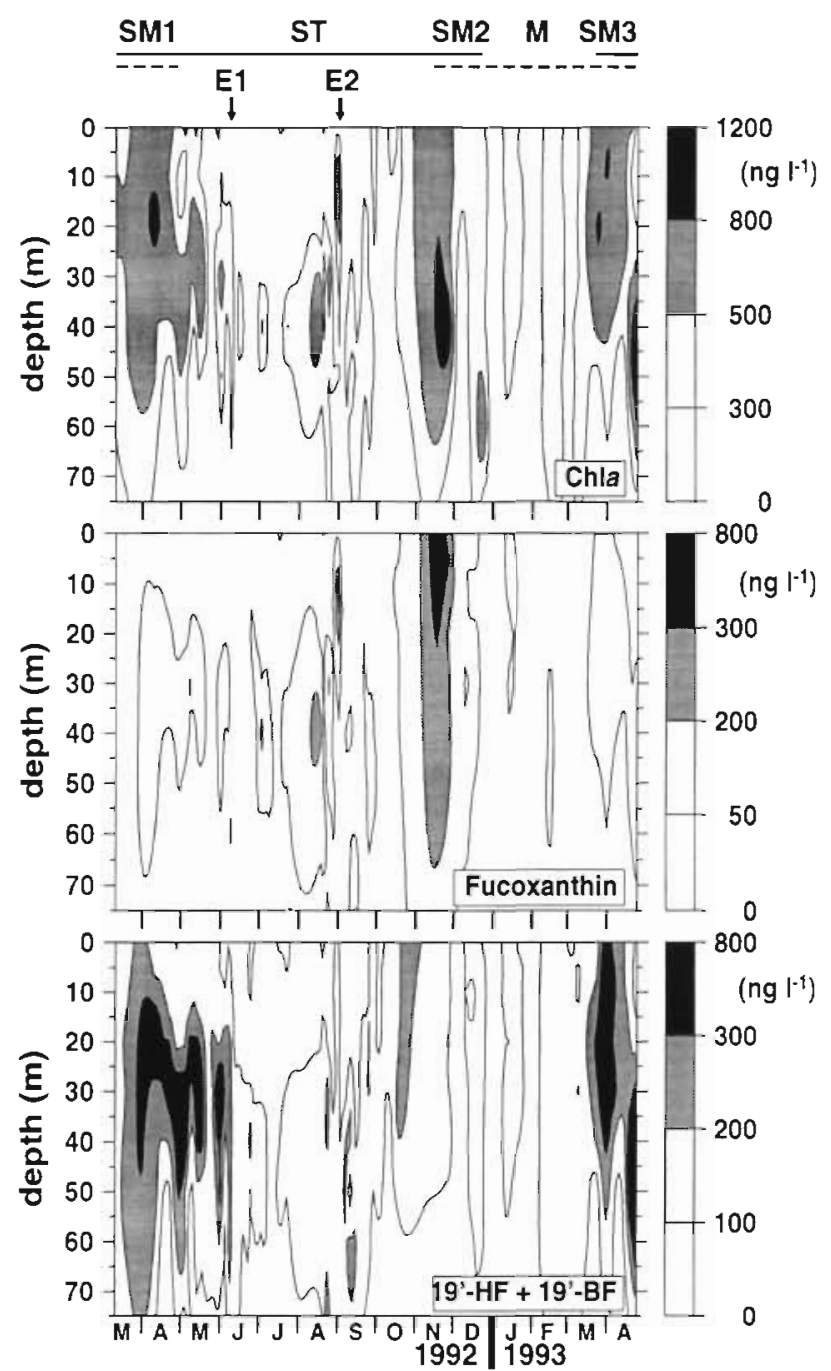

Fig. 5. Vertical distribution of chlorophyll a (Chl a), fucoxanthin and $19^{\prime}$-hexanoyloxyfucoxanthin $+19^{\prime}$-butanoyloxyfucoxanthin (19'-HF+19'-BF) concentration at Stn B between March 1992 and April 1993. Uppermost part of figure refers to stratification conditions as defined in Fig. 1 (stratification index.)

which is a priori impossible to set up for open ocean waters, allowed us to investigate in detail the close linkage between hydrodynamic and phytoplankton dynamics and, in particular, allowed us to evaluate the time necessary for the system to become stable again.

The recorded average chl $a+\mathrm{Dv}-\mathrm{Chl} a\left(24 \mathrm{mg} \mathrm{m}^{-2}\right)$ is well within the range of those zones considered as oligotrophic (e.g. Packard \& Dortch 1975, Dortch \& Packard 1989, Ondrusek et al. 1991, Li et al. 1992). However, the variability of this autotrophic biomass concentration (range $=13$ to $48 \mathrm{mg} \mathrm{chl} a+\mathrm{Dv}-\mathrm{chl} a$ $\mathrm{m}^{-2}$, variation coefficient $=34 \%$, as well as the change in phytoplankton community structure, shows that the system displays a wide range of trophic conditions which are principally linked to hydrodynamics. Let us

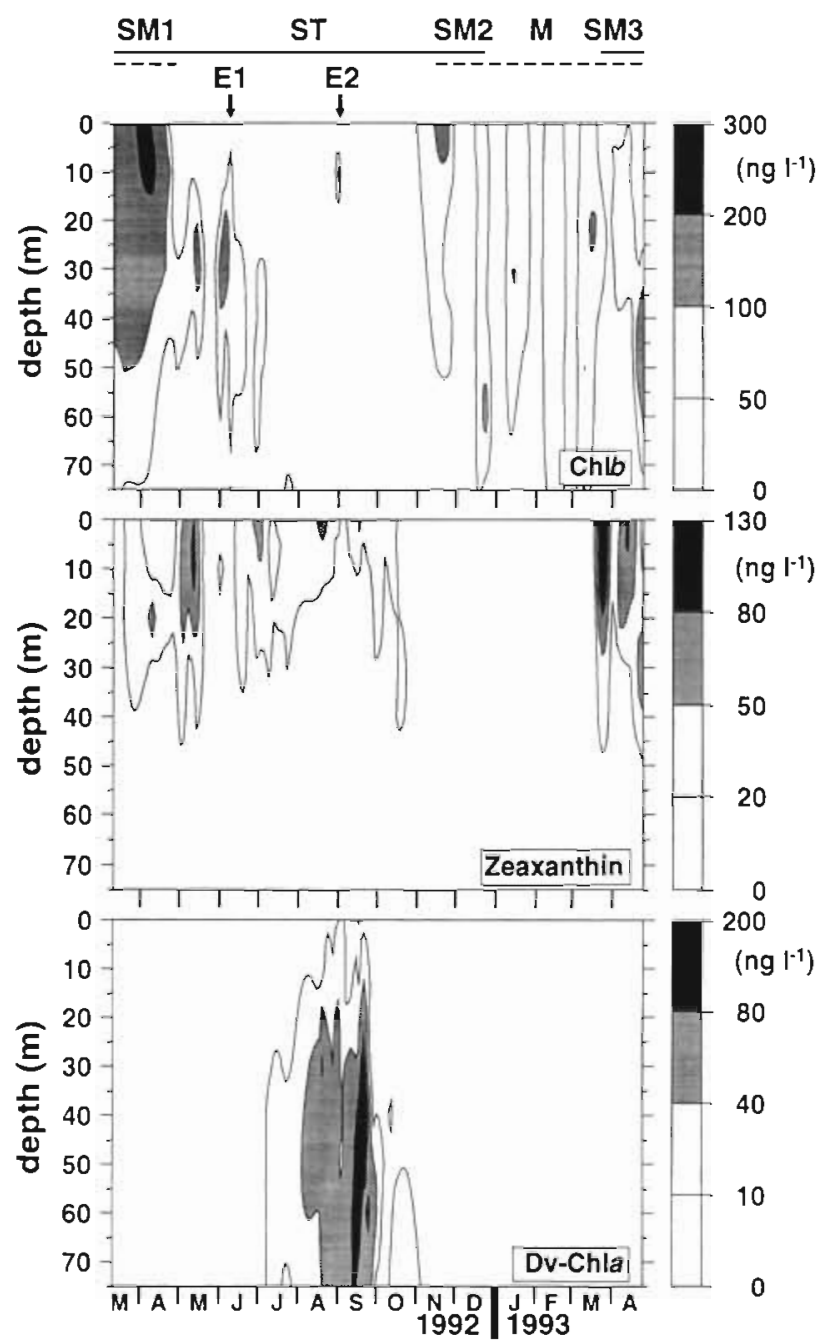

Fig. 6. Vertical distribution of chlorophyll $b(\mathrm{Ch} l b)$, zeaxanthin and divinyl chlorophyll a (Dv-Chl a) concentration at Stn B between March 1992 and April 1993. Uppermost part of figure refers to stratification conditions as defined in Fig. 1 (stratification index)

examine in detail the phytoplankton signature of typical hydrological situations.

Diatoms are recognized as the most opportunistic species as far as taking advantage of nutrient availability is concerned (Fogg 1991) and as such, are a likely contributor to new production in the open ocean (Goldman 1993, Claustre 1994). Never theless, evidence also suggests that, in deep mixed layers, diatoms do not dominate, probably as a consequence of limited photoadaptational ability. Therefore, most of the diatom bloom records are generally restricted to the spatio-temporal transition between mixed and stratified conditions (Kiørboe 1993, Claustre et al. 1994). These conditions offer the best compromise between light and nutrient availability because the associated 
turbulence appears to be a prerequisite for nutrient uptake and floatability in such generally large cells (review in Fogg 1991, Chisholm 1992, Kiorboe 1993). During the period studied, 1 fucoxanthin bloom was associated with such a temporal transition between stratified and mixed conditions (SM2; Figs. $2 \& 4$ ), and it was matched by a shift of phosphate uptake dominance from the 1 to $5 \mathrm{~mm}$ to the $>10 \mu \mathrm{m}$ fraction in a separate study (Dolan et al. 1995), confirming the advantage of diatoms under these conditions. However, other diatom increases in this study were observed during the stratified period and were restricted to a limited band in the water column. Particularly during the second wind-driven event (E2; Fig. 5), the highest fucoxanthin concentrations of this study (up to $800 \mathrm{ng} \mathrm{l}^{-1}$ ) were recorded between 5 and $10 \mathrm{~m}$ (Fig. 5). Following the wind event, the surface waters were replenished with nutrients (the $0.1 \mu \mathrm{M}$ nitrate level reached $30 \mathrm{~m}$ ) and the water was stable enough (Fig. 1) for diatoms to use such a nutrient pulse. It has also been suggested that periodic diatom development occurs during the stratification in the Spanish Mediterranean coastal waters (Latasa et al. 1992); such events correspond to the large phytoplankton new production scheme of Goldman (1993), who suggested that, in stratified oligotrophic ocean, most of the new production may be due to temporally and spatially (vertical) limited diatom blooms.

One of the surprises of this investigation was the lack of the classical spring diatom bloom generally associated with the beginning of water stabilization in the
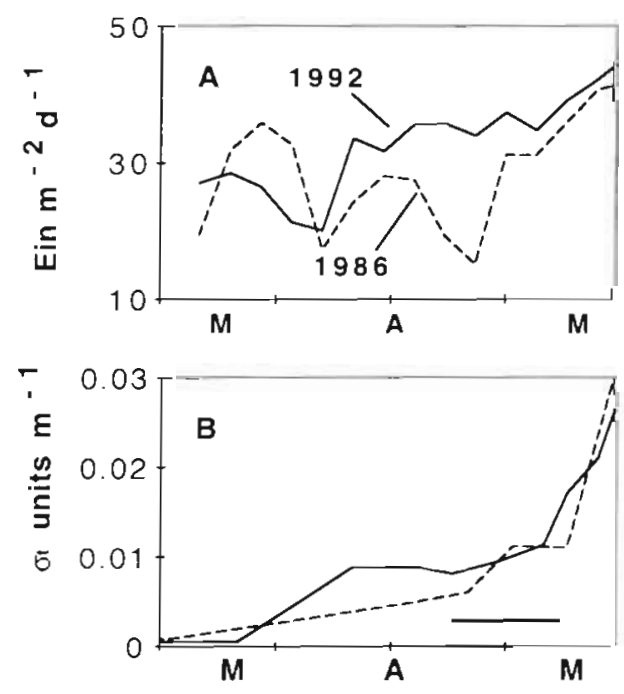

Fig. 7. Comparison between environmental conditions for the 1986 spring diatom bloom (data from Etienne et al. 1991) and the 1992 spring where no diatom bloom occurred. (A) Irradiance (Ein $\left.\mathrm{m}^{-2} \mathrm{~d}^{-1}\right)$. (B) Stratification index $\left\{\sigma_{t}\right.$ units $\mathrm{m}^{-1}$ ). The horizontal line in (B) shows bloom period according to Claustre et al. (1989)
Mediterranean Sea (Claustre et al. 1989, Morel \& André 1991). No remarkable chlorophyll a increase was recorded at this time (Fig. 2), and phytoplankton was dominated by nano-sized taxa with the highest contribution recorded in this study ( $85 \%$ on 9 June; Fig. 4). When 1992 hydrographic conditions are compared to that of a typical diatom bloom year (1986) at the same location (Etienne et al. 1991), the diatom bloom occurred just before the water column abruptly stabilized and coincided with an increase of irradiance (Fig. 7). Density conditions in 1992 were slightly stronger and irradiance increased earlier (March-April). This difference seems to be important for the bloom-forming species. Light penetration may be critical in spring bloom formation (Townsend et al. 1992, 1994), but in this study, irradiance increase may have occurred when the water column was not stable enough. Therefore, during this transition period, the low light regime may have prevailed for a longer time (by mixing). Such conditions can be better exploited by nano-sized flagellates (see below), and, therefore, when light (and stabilization) became optimal for diatom development, nutrients were at this time depleted or at low levels.

Nanoflagellates containing $19^{\prime}$-BF and 19'-HF are the largest contributor to chlorophyll a (all period mean $=45 \%$ ) in this study. The general distribution of this group is remarkable with respect to 3 main aspects: (1) their ubiquity; (2) the relative stability of their pigment concentration over large scales; and (3) their ability to 'bloom' in specific conditions. The pigments $19^{\prime}-\mathrm{HF}$ and $19^{\prime}$-BF have been reported for most oceanic conditions (Gieskes \& Kraay 1986 , Gieskes et al. 1988, Everitt et al. 1990, Williams \& Claustre 1991, Barlow et al. 1993). Superimposed on. this ubiquity, the phytoplankton biomass which is characterized by $19^{\prime}$-BF and $19^{\prime}$-HF shows the lowest quantitative variation. Temporally, this clearly appears in the present data where the flagellate markers present the lowest variability over an 1 yr study (variation coefficient $=38 \%$, Table 3 ). This stability has also been described spatially, since 19'-HF and 19'-BF have been reported to be the most stable taxonomic markers over a large range of trophic conditions in the Atlantic (Claustre 1994) and over a cross frontal section (Claustre et al. 1994). The relative ubiquity and stability of this group, whatever the water masses are, may result either from a large adaptability of this phytoplankton group or from a large diversity of species. In fact, chrysophytes and prymnesiophytes are the most wellknown phytoplankton classes with $19^{\prime}$-BF and $19^{\prime}-\mathrm{HF}$, but the recent description of new classes like pelagophytes (Andersen et al. 1993) which contain 19'-BF as their main marker suggest that nano- and certainly pico-eukaryotic fractions are not very well known. Further work is required on taxonomy and physiology 
of this group in order to better understand their dynamics. Nevertheless, on a smaller scale, this stability of flagellate biomass is not always the rule; some physical features are associated with higher 19'-BF and $19^{\prime}-\mathrm{HF}$ concentrations: this is the case for transitional periods between mixed and stratified conditions (SM1 and SM3, Figs. 4 \& 5). High biomasses of flagellates have also been described for an end diatom bloom situation (Barlow et al. 1993), a transitional situation (Claustre et al. 1994), or even at specific depths (at and below the nitracline) in the stratified tropical oligotrophic ocean (Claustre \& Marty 1995). Nevertheless, these 'elevated' biomasses never reached those generally recorded for diatom blooms. There is increasing evidence that the biomass control in the pico- and nano-sized plankton domain is probably carried out by grazers (more likely from the microbial loop) with growth rates that respond over the same time scale as the autotrophic groups themselves (e.g. Banse 1992). This has been particularly demonstrated for the area studied (Bernard 1991) and it is likely that grazers control the increase of the pico- and nano-phytoplankton standing stocks. In contrast, the time lag between the development of micro-sized cell grazers (i.e. copepods) and diatoms, allow diatoms to bloom (e.g. Fogg 1991, Kiørboe 1993).

Chlorophyll $b$-containing flagellates represented the third most important group that contributes to total chlorophyll a and were associated with mixed conditions. This group also responded to mixing events as evidenced by increases in chlorophyll $b$ concentrations during the mixed period (Fig, 6). During this last period the populations could be continuously mixed far from the euphotic zone so light could limit their growth (André 1990). Chlorophyll $b$ is the main auxiliary photosynthetic pigment of this group and it could be responsible for the predominance of green flagellates at low light levels because its absorption characteristics permit the absorption in the blue-violet spectrum (Glover et al. 1986). Claustre et al. (1994) showed that a high biomass of flagellates (green and chlorophyll c-containing) was present in the transient situations of the Almerian-Oran front (Mediterranean Sea) associated with nutrient enrichment, and they considered it as 'typical' of such transition conditions.

Within the prokaryotic group, the differences between cyanobacteria and prochlorophyte distribution are evident at 2 levels: (1) prochlorophytes were exclusively associated with stratified waters while cyanobacteria maximum abundances were recorded during SM1 and
SM3 or at the beginning of stratification. (2) Cyanobacteria accumulated in surface layers, prochlorophytes at depth. In this study, the stability of the water column seemed to be a prerequisite for prochlorophyte development. This observation is in agreement with now numerous records of prochlorophytes for stratified conditions in the open ocean (Chisholm et al. 1988, Neveux et al. 1989, Campbell \& Vaulot 1993). But in special cases, like winter mixed conditions in the Mediterranean Sea or semi-mixed conditions in the Sargasso Sea, the presence of prochlorophytes (at low abundance) has also been reported (Olson et al 1990, Vaulot et al. 1990, Goericke \& Welschmeyer 1993).

As already reported, increased cyanobacteria concentrations in surface layers (Campbell \& Carpenter 1986, Gieskes \& Kraay 1986, Claustre \& Marty 1995) may be due to their ability to be photosynthetically competent in high light intensities (Kana \& Glibert 1987 ) or to their ability to absorb photons in the green domain (phycobilins; Ong et al. 1986). But, for typical
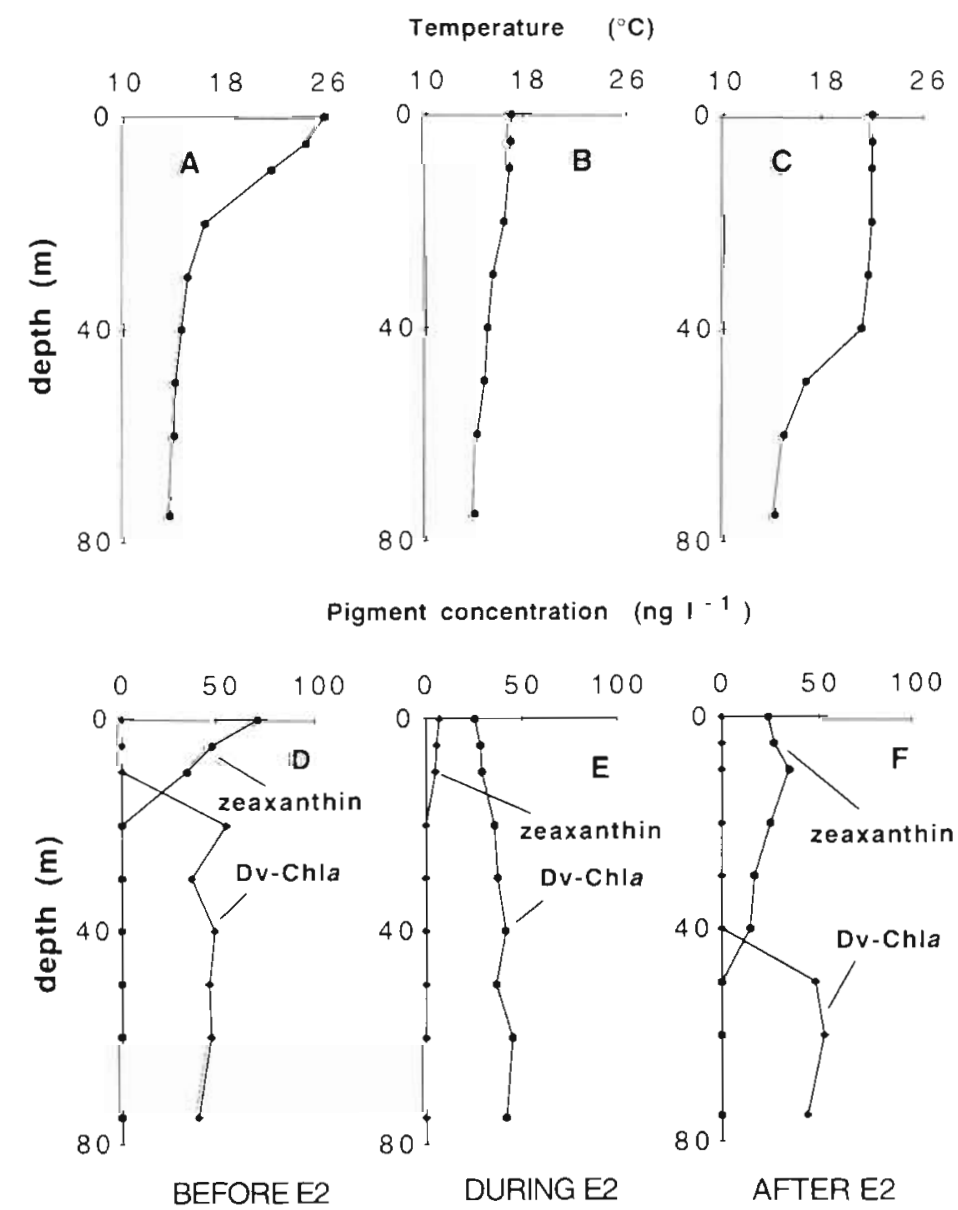

Fig. 8. Typical depth profiles of temperature, divinyl chlorophyll a (DvChl a) and cyanobacteria zeaxanthin before ( $A$ and $D)$, during ( $B$ and E) and after ( $C$ and $F$ ) the hydrographic perturbation $E 2$ (see Fig. 1) of September 1992 at Stn B 
oligotrophic conditions, the biomasses of prochlorophytes and cyanobacteria are nearly the same (Letelier et al. 1993, Claustre \& Marty 1995), which was not the case here during stratified conditions. In stratified oligotrophic oceans cyanobacteria grow in layers where nitrate concentrations are very low. However, in this study the highest cyanobacteria abundances were observed in semi-mixed conditions where nitrates were relatively abundant, suggesting adaptability of the cyanobacteria (e.g. Waterbury et al. 1979, Glover et al. 1988).

In the stratified oligotrophic open ocean, prochlorophytes are distributed throughout the water column, which raises the possibility that several prochlorophyte species or types may exist to match the large variability over the depth (0 to $200 \mathrm{~m}$ ) of light-nutrient conditions (Vaulot et al. 1990, Campbell \& Vaulot 1993). This is also suggested by observations of the differences in pigment ratios from the Sargasso Sea and cultured strains (Goericke \& Repeta 1993). In this study, prochlorophytes were virtually absent from the surface layer, suggesting that the population recorded here may more likely be adapted to low light/high nutrient conditions (cf. Campbell \& Vaulot 1993). This observation is supported by the dynamics of prokaryotes associated with the E2 event (Fig 8). Before the event, when the water column was stratified, a typical profile of zeaxanthin and divinyl-chlorophyll a suggested that cyanobacteria grew at the surface and prochlorophytes at depth. The event induced a mixing of the water column and phytoplankton, resulting in a homogeneous distribution of prochlorophytes. Prochlorophytes did not appear to increase in concentration under such conditions, and as soon as stratification was re-established, they showed a distribution typical of low light/high nutrient species.

\section{CONCLUDING REMARKS}

The present study allowed us to link the hydrographic structures (from complete mixing to strong stratification) to the development, maintenance and succession of the phytoplankton communities (at the taxon level) from an oligotrophic area of the northwestern Mediterranean Sea. Picoplanktonic prokaryotes (cyanobacteria and prochlorophytes) were unable to prosper in mixed water conditions, and particularly prochlorophytes were the most sensitive since the highest divinyl chlorophyll a concentrations, mainly in deep layers, were associated with a strong stratification. Prymnesiophytes and chrysophytes appear to be the most abundant and seem able to adapt to.a wide range of water column hydrographic structures. This property may explains why this group appears to be ubiquitous in most of the world's oceans. Diatoms accumulate mainly in semi-mixed conditions, but while these conditions are necessary, they are not sufficient. Finally, the green chlorophyll $b$-containing flagellates appear to require strong mixing and, similar to diatoms, are able to quickly respond to atmospheric events that enhance homogenization and replenish surface layers with nutrients. Our results suggest therefore that, while different phytoplankton taxa are generally adapted to specific water column conditions, this is not always the case, especially at small scales where specific light/nutrient requirements are important.

Acknowledgements. This work was supported by the DYFAMED program (JGOFS-France) and was partially funded by the Consejo Nacional de Ciencia y Tecnologia (México), grant to J. B.-G. Thanks to: J. Dolan, R. Williams, R. Goericke and the anonymous reviewers for comments; P. Chang and J. Dolan for improvements in the English of the manuscript; R. Charra and D. Betti for field assistance, M. D. Pizay for nitrate analysis; and B. Gentili for some figures. Contribution to MAST-MTP Geodyme subproject (MAS $2 \mathrm{CT}$ 930061).

\section{LITERATURE CITED}

Andersen AL, Sauders GG, Paskind GW, Sexton JP (1993) Ultrastructure and $18 \mathrm{~S}$ rRNA gene sequence for Pelagomonas calseolata gen. et $\mathrm{sp}$. nov and the description of a new algal class, the Pelagophyceae classis nov. J Phycol 29:701-715

André JM (1990) Télédétection spatiale de la couleur de la mer: algorithmique d'inversion des mesures du coastal zone color scanner Application à l'étude de la Méditerranée Occidentale. Thése de l'Université Pierre et Marie Curie, Paris VI

Arpin N, Svec WA, Liaaen-Jensen S (1976) New-fucoxanthinrelated carotenoids from Coccolithus huxleyi. Phytochemistry 15:529-532

Banse K (1992) Grazing, temporal changes of phytoplankton concentrations, and the microbial loop in the open sea. In: Falkowski PG, Woodhead AD (eds) Primary productivity and biochemical cycles in the sea. Plenum Press, New York, p 409-440

Barlow RG, Mantoura RF, Gough MA, Fileman TW (1993) Pigment signatures of the phytoplankton composition in the northeastern Atlantic during the 1990 spring bloom. Deep Sea Res 40:459-477

Bernard C (1991) Comportement trophique des principaux ciliés pélagiques marins en Mer Ligure: phagotrophie, mixotrophie et autotrophie. PhD thesis, Université BlaisePascal Clermont-Ferrand II, France

Bêthoux JP, Prieur L (1983) Hydrologie et circulation en Méditerranée Nord-occidentale. Pétrole Techniques 299: $25-34$

Bjornland T, Guillard RRL, Liaaen-Jensen S (1988) PhaeocystIs sp. clone 667-3: a tropical marine prymnesiophyte with fucoxanthin and 19'-acyloxyfucoxanthins as chemosystematic carotenoid markers. Biochem Syst Ecol 16: $445-452$

Campbell Li Carpenter EJ (1986) Diel patterns of cell division in marine Synechococcus spp. (Cyanobacteria): the use of 
the frequency of dividing cells technique to measure growth rate. Mar Ecol Prog Ser 32:139-148

Campbell L, Vaulot D (1993) Photosynthetic picoplankton community structure in the subtropical North Atlantic Ocean near Hawaii (station A.LOHA). Deep Sea Res 40: 2043-2060

Chisholm SW (1992) Phytoplankton size. In: Falkowski PG, Woodhead AD (eds). Primary productivity and biogeochemical cycles in the sea. Plenum Press, New York, p 213-237

Chisholm SW, Frankel SL, Goericke R, Olson RJ, Palenik B, Waterbury JB, Wesr-Johnsrud L, Zettler ER (1992) Prochlorococcus marinus nov gen. nov. sp. an oxiphototrophic marine prokaryote containing divinyl chlorophyll $a$ and $b$. Arch Microbiol 157:297-300

Chisholm SW, Olson RJ, Zettler ER, Goericke R, Waterbury JB, Welschmeyer N (1988) A novel free-living prochlorophyte abundant in the oceanic euphotic zone. Nature 334 : $340-343$

Claustre $\mathrm{H}$ (1994) The trophic status of various oceanic provinces as revealed by phytoplankton pigment signatures. Limnol Oceanogr 39:1207-1211

Claustre H, Kerhervé P, Marty JC, Prieur L, Hecq JH (1994) Phytoplankton distribution associated with a geostrophic front: ecological and biogeochemical implications. J mar Res 52:711-742

Claustre H, Marty JC (1995) Specific phytoplankton biomasses and their relation to primary production in the tropical north Pacific. Deep Sea Res (in press)

Claustre, H, Marty JC, Cassiani L (1989) Intraspecific differences in the biochemical composition of a diatom dunng a spring bloom in Villefranche-sur-mer Bay, Mediterranean Sea. J exp mar Biol Ecol 1.29:17-32

DiTullio GR, Laws EA (1991) Impact of an atmosphericoceanic disturbance on phytoplankton community dynamics in the North Pactfic Central Gyre. Deep Sea Res 38:1305-1329

Dolan JR, Thingstad TF, Rassoulzadegan F (1995) Phosphate transfer between microbial size-fractions in Villefranche Bay (N. W. Mediterranean Sea) France in autumn 1992. Ophelia 41:71-85

Dortch Q, Packard TT (1989) Differences in biomass structure between oligotrophic and eutrophic marine ecosystems. Deep Sea Res 36:223-240

Etienne M. Corre MC, Dallot S, Nival P (1991) Observations hydrologiques à une station côtière méditerranéenne. Point B - rade de Villefranche-Sur-Mer $\left(43^{\circ} 41^{\prime} 10^{\prime \prime} \mathrm{N}\right.$ $\left.7^{\circ} 19^{\prime} 00^{\prime \prime} \mathrm{E}\right)$. Campagnes Océanographiques Françaises IFREMER, no 14

Everitt DA, Wright SW, Volkman JK, Thomas DP, Lindstrom EJ (1990) Phytoplankton community compositions in the western equatorial Pacific determined from chlorophyll and carotenoid pigment distributions. Deep Sea Res 37 975-997

Fogg GE (1991) The phytoplankton ways of life. New Phytol 118:191-232

Gieskes WW, Kraay GW (1983) Dominance of cryptophyceae during the phytoplankton spring bloom in the central North Sea detected by HPLC analysis of pigments. Mar Biol 75:179-185

Gieskes WW, Kraay GW (1986) Floristic and physiological differences between the shallow and the deep nanophytoplankton community in the euphotic zone of the open tropical Atlantic revealed by HPLC analysis of pigments. Mar Biol 91:567-576

Gieskes WW, Kraay GW, Nontji A, Setiapermana D, Sutomo S (1988) Monsoonal alternation of a mixed and a layered structure in the phytoplankton of the Banda Sea (Indonesia): mathematical analysis of algal pigment fingerprints Neth J Sea Res 22:123-137

Glover EH, Keller MD, Guillard RL (1986) Light quality and oceanic ultraphytoplankters. Nature 319:142-143

Glover HE, Prezelin BB, Campbell L, Wyman M. Garside C (1988) A nitrate dependent Synechococcus bloom in surface Sargasso Sea water. Nature 331:161-163

Goericke R, Repeta D (1992) The pigments of Prochlorococcus marinus: the presence of divinyl-chlorophyll $a$ and $b$ in a marıne prokaryote. Limnol Oceanogr 37:425-433

Goericke R, Repeta D (1993) Chlorophylls $a$ and $b$ and divinyl chlorophylls $a$ and $b$ in the open subtropical North Atlantic Ocean. Mar Ecol Prog Ser 101:307-313

Goericke R, Welschmeyer NA (1993) The marine prochlorophyte Prochlorococcus contributes significantly to phytoplankton biomass and primary production in the Sargasso Sea. Deep Sea Res 40:2283-2294

Goldman JC (1993) Potential role of large oceanic diatoms in new primary production. Deep Sea Res 40:159-168

Gostan J (1967) Etude du courant géostrophique entre Villefranche-sur-mer et Calvi. Cah Oceanogr 19:329-345

Guillard RRL, Murphy LS, Foss P, Liaaen-Jensen S (1985) Synechoccocus spp. as likely zeaxanthin-dominant ultraplankton in the North Atlantic Limnol Oceanogr 30 $412-414$

Harris GP (1984) Phytoplankton productivity and growth measurements: past, present and future. J Plankton Res $6: 219-237$

Harrison WG, Head EJH, Horne EPW, Irwin B, Li WKW, Longhurst AR, Paranjape MA, Platt T (1993) The western North Atlantic Bloom Experiment. Deep Sea Res II 40: $279-305$

Hooks CE, Bidigare RR, Keller MD, Guillard RRL (1988) Coccoid eukaryotic marine ultraplankters with four different HPLC pigment signature. J Phycol 24:571-580

Jeffrey SW (1974) Profiles of photosynthetic pigments in the central North Pacific Ocean. Mar Biol 34:101-110

Jeffrey SW (1976) A report of green algae pigments in the central North Pacific Ocean. Mar Biol 37:33-37

Kana TM, Glibert PM (1987) Effect of irradiance up to $2000 \mu \mathrm{E}$ $\mathrm{m}^{-2} \mathrm{~s}^{-2}$ on marine Synechococcus WH7803-1. Growth, pigmentation and cell composition. Deep Sea Res 34:179-495

Kana TM, Glibert PM, Goericke R, Welschmeyer NA (1988) Zeaxanthin and $\beta$-carotene in Synechococcus WH7803 respond differently to irradiance. Limnol Oceanogr 33: $1623-1627$

Kiørboe T (1993) Turbulence, phytoplankton cell size, and the structure of pelagic food webs. Adv mar Biol 29:1-72

Latasa M, Estrada M, Delgado M (1992) Plankton-pigment relationship in the Northwestern Mediterranean during stratification. Mar Ecol Prog Ser 88:61-73

Letelier RM, Bidigare RR, Hebel DV, Ondrusek M, Winn CD, Karl DM (1993) Temporal variability of phytoplankton community structure based on pigment analysis. Limnol Oceanogr 38:1420-1437

Li WKW, Dickie PM, Irwin BD, Wood AM (1992) Biomass of bacteria, cyanobacteria, prochlorophytes and photosynthetic eukaryotes in the Sargasso Sea. Deep Sea Res 39: $501-519$

Liaaen-Jensen S (1979) Carotenoids - a chemosystematic approach. Pure appl Chem 51:661-675

Liaaen-Jensen S (1985) Carotenoids of lower plants - recent progress. Pure appl Chem 57:649-658

Liaaen-Jensen S (1990) Marine carotenoids - selected topics. New J Chem 14:747-759

Minas, HJ, Bonin MC (1988) Oxygénation physique et bio- 
logique de la Mediterranée nord-occidentale en hiver et au printemps. In: Minas HJ, Nival P (eds) Océanographie pélagique méditerranéenne. Oceanol Acta spec issue 9: $123-132$

Morel A, André JM (1991) Pigment distribution and primary production in the Western Mediterranean as derived and modeled from coastal zone color scanner observation. J geophys Res 96:12685-12698

Neveux J, Vaulot D, Courties C. Fukai E (1989) Green photosynthetic bacteria associated with a deep chlorophyll maximum of the Sargasso Sea. Cr Acad Sci Paris 308:9-14

Nival P, Corre MC (1976) Variation annuelle des caractéristiques hydrologiques de surface dans la rade de Villefranche-sur-mer. Annls Inst Oceanog, Monaco 52:57-78

Olson RJ, Chisholm SW, Zettler ER, Altabet MA, Dusenberry JA (1990) Spatial and temporal distribution of prochlorophyte picoplankton in the North Atlantic Ocean. Deep Sea Res 37:1033-1051

Ondrusek ME, Bidigare RR, Sweet ST, Defreitas DA, Brooks JM (1991) Distribution of phytoplankton pigments in the North Pacific Ocean in relation to physical and optical variability. Deep Sea Res 38:243-266

Ong LJ, Glazer AN, Waterbury JB (1986) An unusual phycoerythrin from a marine cyanobacterium. Science 224 $80-82$

Packard TT, Dortch Q (1975) Particulate protein-nitrogen in North Atlantic surface waters. Mar Biol 33:347-354

Partensky F, Hoepffner N, Li WKW, Ulloa O, Vaulot D (1993) Photoacclimation of Prochlorococcus sp. (Prochlorophyta) strains isolated from North Atlantic and the Mediterranean Sea. Plant Physiol 101:285-296

Peterson W, Bellantoni DC (1987) Relationship between watercolumn stratification, phytoplankton cell size and copepod fecundity in Long Island Sound and off central Chile. S Afr J mar Sci 5:411-421

Rassoulzadegan F (1979) Cycles de la distribution de différentes catégories de particules du seston et essai d'identification des principales poussées phytoplanctoniques dans les eaux néritiques de Villefranche-Sur-Mer J exp mar Biol Ecol 38:41-56

This article was submitted to the editor
Townsend DM, Cammen LM, Holligan PM, Campbell DE, Pettigrew NR (1994) Causes and consequences of variability in the timing of spring phytoplankton blooms. Deep Sea Res 41:747-765

Townsend DM, Keller MD, Sieracki ME, Ackleson SG (1992) Spring phytoplankton blooms in the absence of vertical water column stratification. Nature 360:56-62

Tréguer P, Le Corre P (1975) Manuel d'analyse des sels nutr1tifs dan l'eau de mer (utilisation de l'autoanalyzer ll Technicon). Laboratoire d'Océanographie chimique, Université de Bretagne Occidentale, 2nd edn, Brest, France

Vaulot D, Partensky F, Neveux J, Mantoura RFC, Llewellyn CA (1990) Winter presence of prochlorophytes in surface waters of the northwestern Mediterranean Sea. Limnol Oceanogr 35(5):1156-1164

Verity PG, Stoecker DK, Sieracki ME, Nelson JR (1993) Grazing, growth and mortality of microzooplankton during the 1989 North Atlantic spring bloom at $47^{\circ} \mathrm{N}, 18^{\circ} \mathrm{W}$. Deep Sea Res 40:1793-1814

Waterbury JB, Watson SW, Guillard RRL, Brand LE (1979) Widespread occurrence of a unicellular, marine, planktonic cyanobacterium. Nature 277:292-294

Weeks A, Conte $\mathrm{MH}$, Harris RP, Bedo A, Bellan I, Burkill PH, Edwards ES, Harbour DS, Kennedy H, Llewellyn C, Mantoura RFC, Morales CE, Pomroy AJ, Turley CM (1993) The physical and chemical environment and changes in community structure associated with bloom evolution: the Joint Global Flux Study North Atlantic Bloom Experiment. Deep Sea Res II 40:347-368

Welschmeyer $N$ (1994) Prochlorophytes and the transition between coastal and oceanic food webs. EOS 75(3): 194

Williams R, Claustre H (1991) Photosynthetic pigments as biomarkers of phytoplankton populations and processes involved in the transformation of particulated organic matter at the Biotrans site $\left(47^{\circ} \mathrm{N}, 20^{\circ} \mathrm{W}\right)$. Deep Sea Res 38 : $347-355$

Wright SW, Jeffrey SW (1987) Fucoxanthin pigment markers of marine phytoplankton analyzed by HPLC and HPTLC Mar Ecol Prog Ser 38:259-266

Manuscript first received: November 11, 1994 Revised version accepted: February 22, 1995 